\title{
SOWING DENSITY AND CLIPPING MANAGEMENT: EFFECTS ON THE ARCHITECTURE AND YIELD OF DUAL-PURPOSE WHEAT
}

\author{
DENSIDADE DE SEMEADURA E MANEJOS DE CORTE: EFEITOS NA \\ ARQUITETURA E RENDIMENTO DO TRIGO DE DUPLICAÇÃO
}

\section{Francielen Lima da SILVA ${ }^{1}$; Ivan Ricardo CARVALHO ${ }^{2 *}$; Maurício HorbachBARBOSA ${ }^{1}$; Giordano GelainCONTE ${ }^{1}$; Danieli Jacoboski HUTRA ${ }^{2}$; Natã Balssan MOURA ${ }^{2}$; Velci Queiróz de SOUZA ${ }^{3}$}

1. Universidade Federal de Pelotas, Programa de Pós Graduação em Botânica, Capão do Leão, RS, Brasil; 2. Universidade Regional do Noroeste do Estado do Rio Grande do Sul, Departamento de Estudos Agrários, Ijuí, RS, Brasil. carvalho.irc@gmail.com;

3. Universidade Federal do Pampa, São Gabriel, RS, Brasil.

\begin{abstract}
The dual-purpose wheat stands out as a complementary alternative for forage supply during the winter period. Therefore, this work had the objective of evaluate the performance characteristics in five genotypes of dual-purpose wheat submitted to different sowing densities and different clipping managements. The experiment was carried out during the 2016 and 2017 harvests. The experimental design was a randomized block design, organized in a factorial scheme, with five dual-purpose wheat genotypes (BRS Tarumã, BRS Umbu, BRS Figueira, BRS Guatambu and BRS 277) x five sowing densities $(75,150,225,300$ and 375 seeds $\mathrm{m}^{2}$ ) x four clipping operations (zero, one, two and three clippings), arranged in three replicates. The measuring of characters were number of fertile tillers, seeds yield, angle of flag leaf, chlorophyll content and flowering. The genotype BRS Tarumâ is superior in number of fertile tillers and chlorophyll index for all the sowing densities, as well, the flowering is influenced direct by clipping managements. The sowing density of 75 seeds $\mathrm{m}^{-2}$ is not indicated for dual-purpose wheat independent of the clipping management. The seeds yield is amplified thought the increase in sowing density, however, advancing in clipping levels there is a decrease in forage yield.
\end{abstract}

KEYWORDS: Triticum aestivum L. Phenotypic plasticity. Intra-specific competition. Canopy adjustment of plants.

\section{INTRODUCTION}

The wheat (Triticum aestivum L.) crop is among the most produced cereals worldwide. Some genotypes may exhibit dual-purpose, thus, the capacity to produce forage and grains in quantities that are sufficiently economical and simultaneous during its cultivation (Koch et al., 2017). The Brazilian domestic consumption of wheat was around 11 million tons of grain in 2018, though the production only reached 5.2 million tons of grain produced (CONAB, 2018). Among the States that stand out in the production of this cereal, Paraná and Rio Grande do Sul account for $86 \%$ of national production (JESUS JUNIOR et al., 2011; SZARESKI, 2018).

The tolerance to clipping managements, as well as high tillering ability propitiated the dualpurpose to certain genotypes of wheat. Providing it as an alternative for forage source to remedy problems arising the lack of fodder during the period between the fall and early winter, since the early seeding can benefit the production chain of dairy and beef (MEINERZ, 2012). In these cases, the establishment of dual-purpose crops allow the farmer to postpone his decision or then reconcile the production of grain and forage production (CARVALHO et al., 2017; HASTENPFLUG, 2009). Wheat cultivars with dual-purpose characteristics can contribute to the intensification of the use of agricultural areas in the winter, allowing the supplying of forage, production of straw for no-till sowing system and reduce dependence of Brazil on importing wheat.

The dual-purpose wheat stands out as a complementary alternative for forage supply during the winter period, mainly in properties that adopt the management system with the integration croplivestock (FONTANELI, 2000). Genotypes with dual-purpose present high green mass yield, long vegetative stage, shorter reproductive period, tolerance to trampling and clipping management, high tillering potential and fast establishment of the culture (MARTIN et al., 2010).

It reveals some care needs regarding the management of the plants, when these are rationally 
followed, the activity results in success in the productive and economic scope. The well-employed management techniques allow increasing the number of clippings, maximize forage extraction and re-growth capacity (CARVALHO et al., 2017). Among the practices used to increase productivity, the arrangement less spaced between the sowing lines allows the increase of the equidistance between the plants, constituting an important alternative to improve the results. However, there is a maximum limit of plants in one given space due to the natural intraspecific competition for nutrients and light (VON PINHO et al., 2008). Therefore, this work had the objective of evaluating the performance characteristics in five genotypes of dual-purpose wheat submitted to different sowing densities and different clipping managements.

\section{MATERIALS AND METHODS}

The experiment was conducted during the 2016 and 2017 harvests in Frederico Westphalen, RS, Brazil, in the coordinates of latitude $27^{\circ} 39^{\prime} 56^{\prime \prime}$ $\mathrm{S}$ and longitude of $53^{\circ} 42^{\prime} 94^{\prime \prime} \mathrm{W}$, with altitude of 490 meters. The soil is classified as Clayey Hapludox and the climate is characterized by Köppen as subtropical Cfa (MORENO, 1961).

The experimental design was a randomized block design, organized in a factorial scheme, with five wheat genotypes (BRS Tarumã, BRS Umbu, BRS Figueira, BRS Guatambu and BRS 277) $x$ five sowing densities $(75,150,225,300$ and 375 seeds $\mathrm{m}^{2}$ ) $\mathrm{x}$ four clipping operations (zero, one, two and three clippings), arranged in three replicates. The experimental units were comprised of 12 rows of 2.0 meters in length, spaced $17 \mathrm{~cm}$, with a utile area of $4,08 \mathrm{~m}^{2}$. In both cropping season analyzed, we used no-till with basic fertilizing of $250 \mathrm{~kg} \mathrm{ha}^{-1} \mathrm{NPK}$ (10-20-20), and $90 \mathrm{~kg} \mathrm{ha}^{-1}$ of nitrogen coverage in the form of urea ( $45 \%$ of $\mathrm{N})$, with application in full tillering stage. The criterion used for realizing the clippings was when more than $75 \%$ of the plants of experimental unit showed height of 30 centimeters, the sections were manually performed leaving $10 \mathrm{~cm}$ of height (CARVALHO, 2015). The control of pests, weeds and diseases were preventively perfomed.

The measuring of characters were performed in ten random plants in the working area of the experimental unit, according to the methodology of Martin et al. (2013). The measured characters were: number of fertile tillers (NT) number of tillers present in the plant that have productive potential of seeds, expressed in units; seeds yield (SY) - productivity per hectare, expressed in $\mathrm{kg} \mathrm{ha}^{-1}$; angle of flag leaf (AF) - the angle at which the last leaf is located in the stem, expressed in degrees; chlorophyll content (CI) were determined by a chlorophyll meter, results are expressed in index and flowering (F) - days until flowering.

The data obtained was submitted to the assumptions of the statistical model aiming to identify the normality of the residues and the homogeneity of the variances residues. Afterwards, it was submitted to analysis of variance at $5 \%$ of probability by the $\mathrm{F}$ test, in order to diagnose the interaction between the dual-purpose wheat genotypes $\mathrm{x}$ seeding density $\mathrm{x}$ clipping management. For the characters that revealed significant interaction were simplified to the simple effects for the qualitative factors (dual-purpose wheat genotypes and clipping management). For the quantitative effects (sowing density), linear regression was performed, where the largest significant degree of the polynomial was tested by the $t$ test at $5 \%$ of probability.

\section{RESULTS AND DISCUSSION}

The variance analysis revealed significance of $5 \%$ of probability for the interaction of dualpurpose wheat genotypes $\mathrm{x}$ seeding density for the characters NT, CI, SY and AF; wheat genotypes $\mathrm{x}$ clipping management for characters F, NT and SY; seeding density $\mathrm{x}$ clipping system for the character NT.

The NT was expressed for five studied genotypes (Figure 1a, Table 1), the genotypes BRS Tarumã and BRS Figueira were responsible for the greatest magnitude of this character when plants were grown in the evaluated density, with the exception of the BRS Figueira genotype at the density of 150 seeds $\mathrm{m}^{-2}$. The BRS 277 genotype presented the smallest magnitudes for NT in relation to the other genotypes. For this character, the best performances of the genotypes were presented when using the density of 75 seeds $\mathrm{m}^{2}$.

For the CI variable, the BRS Umbu genotype showed higher magnitudes for the densities 75, 150, 225 and 300 seeds $\mathrm{m}^{-2}$ (Figure 1b, Table 1), in contrast, in the density of 375 seeds $\mathrm{m}^{-2}$ the BRS Tarumã genotype proved superior to the others. The genotype BRS 277 obtained high performance in all studied seeding densities. For BRS Figueira, increased density leads to decrease in the magnitude of CI. Better arrangements for the studied genotypes are obtained with densities of 75 and 225 seeds $\mathrm{m}^{-2}$. 
Table 1. Averages for number of fertile tillers (NT), chlorophyll index (CI), seed yield (SY) and angulation of the flag leaf (AF) for five dual-purpose wheat genotypes under different seeding densities.

\section{Seed density $\left(\mathrm{s} / \mathrm{m}^{2}\right) \quad$ BRS $277 \quad$ BRS Figueira $\quad$ BRS Guatambu $\quad$ BRS Tarumã $\quad$ BRS Umbu}

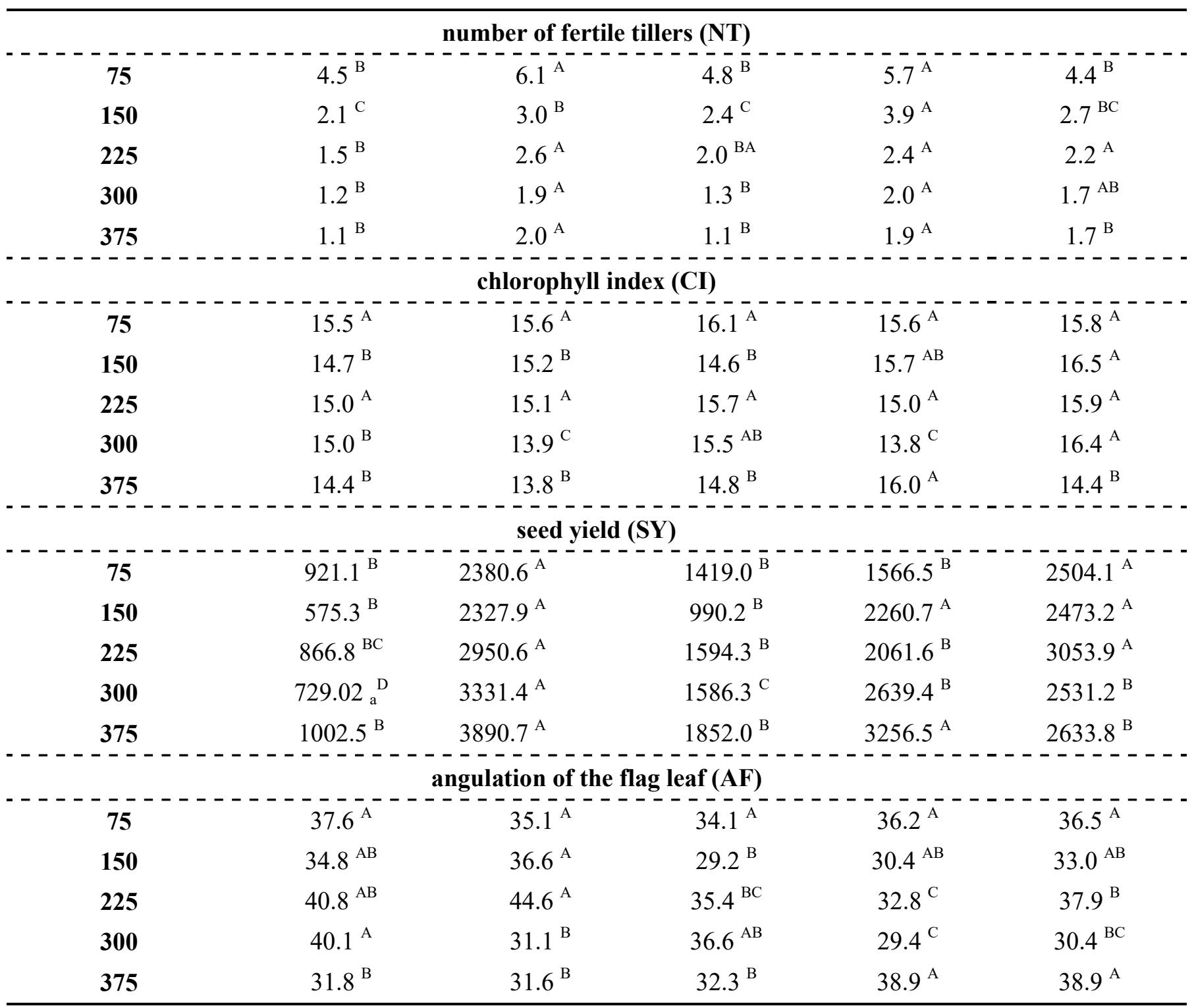

* Means followed by the same capital letter in the line do not differ by $5 \%$ of probability. 


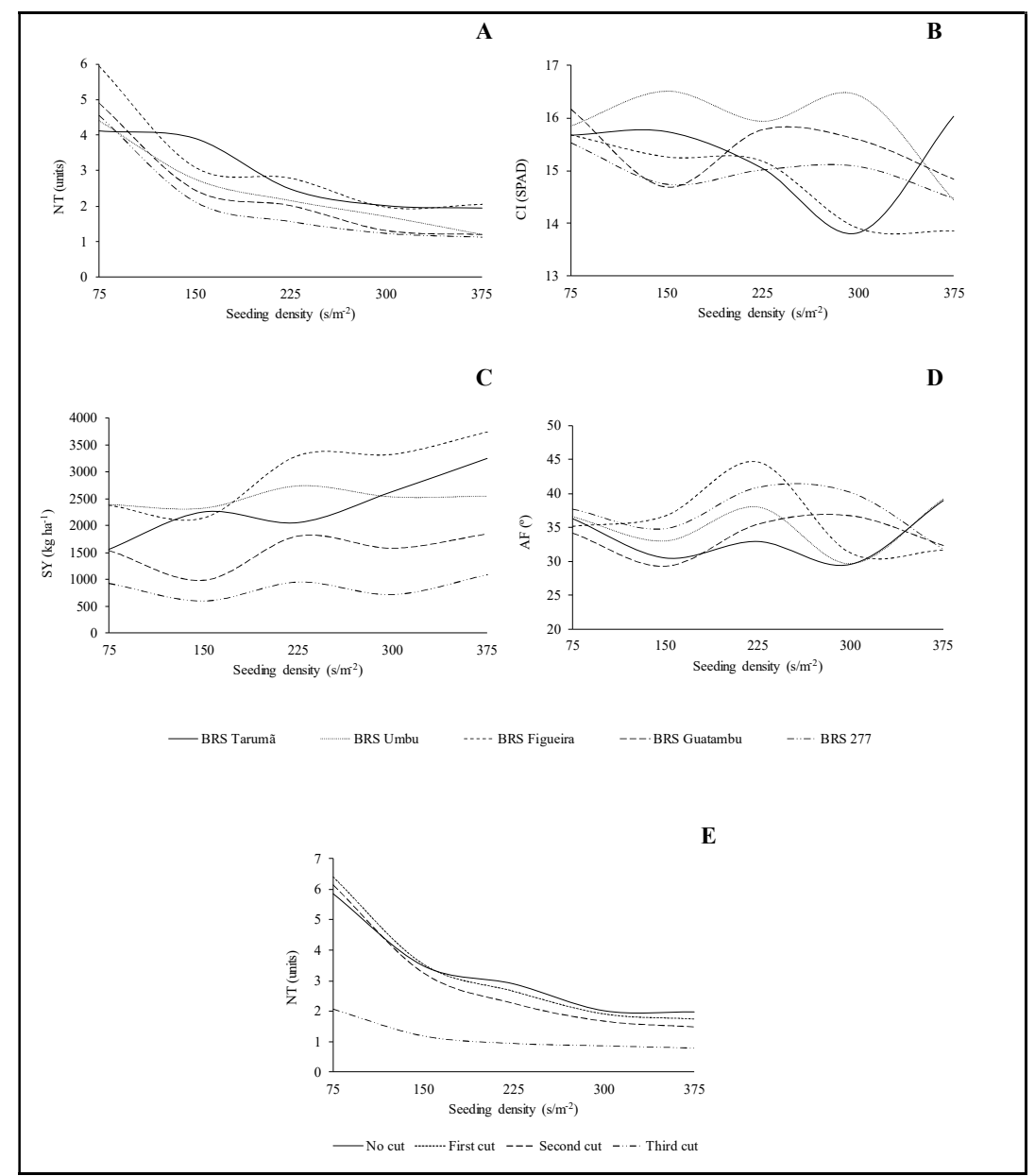

Figure 1. A: number of fertile tillers; B: chlorophyll index; C: seed yield; D: angulation of the flag leaf; E: number of fertile tillers.

The genotype BRS Figueira showed superiority and genotype BRS 277 obtained the smallest magnitudes for the SY character, at the studied densities (Figure 1c, Table 1). It was observed that the highest yields were obtained in the density of 375 seeds $\mathrm{m}^{-2}$, except for BRS Umbu genotype that obtained higher seed yield using 225 seed $\mathrm{m}^{-2}$. Research by Zilio et al. (2017), affirm that the seeding density influences the seed production of the dual-purpose genotypes, in agreement with the results it is evident that the genotypes show similar behavior, however, a general recommendation for the density is not obtained, but there is a need for stratification of the recommendation for genotypes.

For the AF character, the genotype BRS 277 showed to be superior to the others, however with the density of 375 seeds $\mathrm{m}^{-2}$ the genotype BRS Umbu obtained greater magnitude (Figure 1d, Table 1). For BRS Guatambu there were smaller magnitudes in relation to the other genotypes. The reduction of the angle between the stem and the flag leaf can provide better utilization of the incident solar radiation on the crop canopy, provoking reduction of leaves overlapping.

The deployment of the interaction of dualpurpose wheat genotypes $\mathrm{x}$ clipping management (Table 2) revealed significance for the variables NT, $\mathrm{F}$ and SY. For the NT variable in the clipping management, with one and three clippings, the BRS Tarumã was superior (Table 2). The BRS Guatambu and BRS Umbu obtained better performances for this character in the management without clipping. As management is employed with a greater number of clippings, the NT for genotypes decreased. However, there was increment for the character BRS Figueira with on clipping and BRS Tarumã with the second clipping. 
Table 2. Averages for number of fertile tillers (NT), flowering (F) and seed yield (SY) for five dual-purpose wheat genotypes under management of clippings.

\begin{tabular}{|c|c|c|c|c|c|}
\hline Cut & BRS 277 & BRS Figueira & BRS Guatambu & BRS Tarumã & BRS Umbu \\
\hline \multicolumn{6}{|c|}{ number of fertile tillers (NT) } \\
\hline Non cut & $2.7^{\mathrm{B}} *-$ & $3.5^{\mathrm{A}---}$ & $3.0^{\mathrm{B}}$ & $3.8^{--}$ & $3.0^{\mathrm{B}}$ \\
\hline First cut & $2.7^{\mathrm{B}}$ & $4.0^{\mathrm{A}}$ & $2.9^{\mathrm{B}}$ & $3.7^{\mathrm{A}}$ & $2.9^{\mathrm{B}}$ \\
\hline Second cut & $2.5^{\mathrm{C}}$ & $3.3^{\mathrm{B}}$ & $2.6^{\mathrm{C}}$ & $4.0^{\mathrm{A}}$ & $2.3^{\mathrm{C}}$ \\
\hline Third cut & $0.4^{\mathrm{B}}$ & $1.7^{\mathrm{A}}$ & $0.8^{\mathrm{BC}}$ & $1.2^{\mathrm{AC}}$ & $1.5^{\mathrm{A}}$ \\
\hline \multicolumn{6}{|c|}{ flowering $(\mathrm{F})$} \\
\hline Non cut & $119.6^{\mathrm{B}}$ & $110.4^{\mathrm{C}}$ & $117.3^{-}$ & $150.0^{\mathrm{A}}$ & $-\overline{11} \overline{1.6} \overline{\mathrm{C}}^{\mathrm{C}--}$ \\
\hline First cut & $143.0^{\mathrm{A}}$ & $115.0^{\mathrm{C}}$ & $126.6^{\mathrm{B}}$ & $150.0^{\mathrm{A}}$ & $119.6^{\mathrm{BC}}$ \\
\hline Second cut & $150.0^{\mathrm{A}}$ & $131.3^{\mathrm{B}}$ & $150.0^{\mathrm{A}}$ & $150.0^{\mathrm{A}}$ & $144.2^{\mathrm{A}}$ \\
\hline Third cut & $150.0^{\mathrm{A}}$ & $143.0^{\mathrm{A}}$ & $150.0^{\mathrm{A}}$ & $150.0^{\mathrm{A}}$ & $147.6^{\mathrm{A}}$ \\
\hline & & seed yiel & & & \\
\hline Non cut & $1129.0^{\mathrm{E}}-$ & $4804.3^{\mathrm{AB}}-$ & $2427.1 \bar{D}$ & $3292.6^{\bar{C}}$ & $5195.2^{-\mathrm{A}^{-}}$ \\
\hline First cut & $1232.1^{\mathrm{D}}$ & $4325.7^{\mathrm{A}}$ & $2068.0^{\mathrm{C}}$ & $3161.0^{\mathrm{B}}$ & $3570.7^{\mathrm{B}}$ \\
\hline Second cut & $855.2^{\mathrm{B}}$ & $2246.7^{\mathrm{A}}$ & $1270.2^{\mathrm{B}}$ & $2690.4^{\mathrm{A}}$ & $1441.3^{\mathrm{B}}$ \\
\hline Third cut & $59.5^{\mathrm{A}}$ & $528.3^{A}$ & $188.3^{\mathrm{A}}$ & $283.8^{\mathrm{A}}$ & $349.8^{\mathrm{A}}$ \\
\hline
\end{tabular}

* Means followed by the same capital letter in the line do not differ by $5 \%$ of probability.

The BRS Tarumã genotype showed superiority and uniformity for all clipping managements (Table 2). The largest magnitude for this character was reached in the third clipping management for the genotypes presented in this study. The SY character is negatively influenced by the presence of clipping management and the number of times it is used, and this technique should be reviewed in order to improve this character for dual-purpose wheat genotypes. The BRS Umbu presented superiority when not clipped, although not differing from BRS Figueira, which had superior performance for the first and third clipping management. For Martin et al. (2010), clippings management revealed BRS Figueira genotype superior for this character, where there was a decrease in yield of all genotypes. In the use of the two-clipping system, the genotype BRS Tarumã showed the highest seed yield in relation to genotypes BRS 277, BRS Figueira, BRS Guatambu and BRS Umbu.

Table 3. Number of fertile tillers (NT) for five dual-purpose wheat genotypes under different sowing densities and management of clippings.

\begin{tabular}{ccccc}
\hline Seed Density $\left(\mathbf{s} / \mathbf{m}^{\mathbf{2}}\right)$ & No clipping & First clipping & Second clipping & Third clipping \\
\hline $\mathbf{7 5}$ & $5.8^{\mathrm{B}} *$ & $6.5^{\mathrm{A}}$ & $6.1^{\mathrm{AB}}$ & $2.0^{\mathrm{C}}$ \\
$\mathbf{1 5 0}$ & $3.4^{\mathrm{A}}$ & $3.5^{\mathrm{A}}$ & $3.2^{\mathrm{A}}$ & $1.1^{\mathrm{B}}$ \\
$\mathbf{2 2 5}$ & $2.8^{\mathrm{A}}$ & $2.6^{\mathrm{AB}}$ & $2.2^{\mathrm{B}}$ & $0.9^{\mathrm{C}}$ \\
$\mathbf{3 0 0}$ & $2.0^{\mathrm{A}}$ & $1.9^{\mathrm{A}}$ & $1.7^{\mathrm{A}}$ & $0.8^{\mathrm{B}}$ \\
$\mathbf{3 7 5}$ & $1.9^{\mathrm{A}}$ & $1.7^{\mathrm{A}}$ & $1.4^{\mathrm{A}}$ & $0.8^{\mathrm{B}}$ \\
\hline
\end{tabular}

* Means followed by the same capital letter in the line do not differ at $5 \%$ of probability. 
Table 4. Equations for architecture components and productivity of five genotypes of dual-purpose wheat under different seeding densities and management of clippings.

\section{Genotypes \\ BRS 277 \\ BRS Figueira \\ BRS Guatambu \\ BRS Tarumã \\ BRS Umbu \\ BRS 277 \\ BRS Figueira
BRS Guatambu
BRS Tarumã
BRS Umbu}

BRS 277

BRS Figueira

BRS Guatambu

BRS Tarumã

BRS Umbu

BRS 277

BRS Figueira

BRS Guatambu
BRS Tarumã
BRS Umbu

No clipping

First clipping

Second clipping

Third clipping

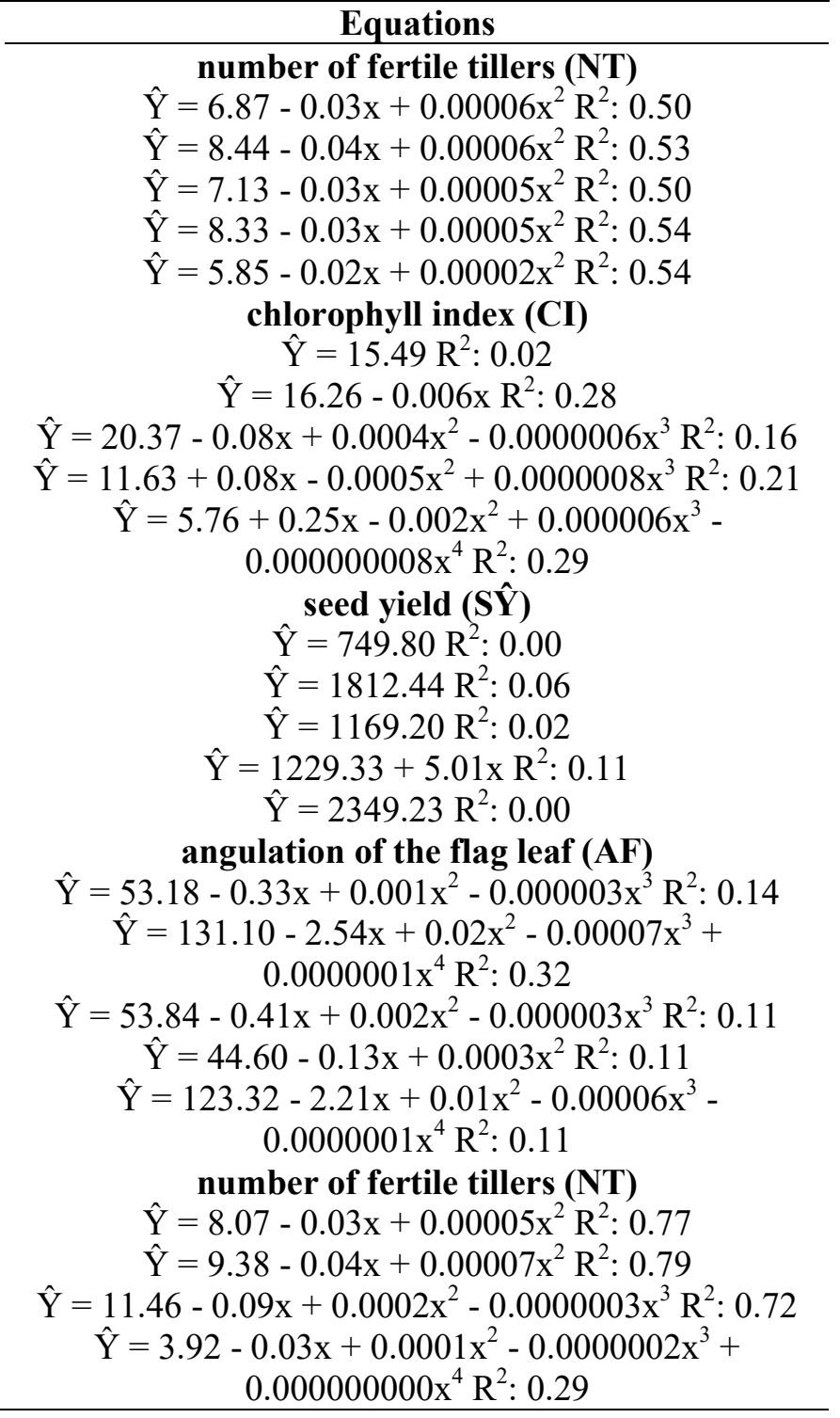

the sowing densities studied, the management system with one clipping was superior, evidencing that for the best performance it is recommended the use of this management system.

\section{CONCLUSIONS}

The genotype BRS Tarumâ is superior in number of fertile tillers and chlorophyll index for all the sowing densities, as well, the flowering is influenced direct by clipping managements.

The sowing density of 75 seeds $\mathrm{m}^{-2}$ is not indicated for dual-purpose wheat independent of the clipping management.

The seeds yield is amplified thought the increase in sowing density, however, advancing in clipping levels there is a decrease in forage yield. 


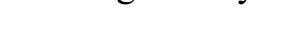

SILVA, F. L. et al.

RESUMO: O trigo de duplo propósito se destaca como uma alternativa complementar para o fornecimento de forragem durante o período de inverno. Portanto, este trabalho teve como objetivo avaliar as características de desempenho de cinco genótipos de trigo de duplo propósito submetidos a diferentes densidades de semeadura e diferentes manejos de corte. O experimento foi realizado durante as safras de 2016 e 2017. O delineamento experimental foi em blocos ao acaso, organizado em esquema fatorial, com cinco genótipos de trigo de duplo propósito (BRS Tarumã, BRS Umbu, BRS Figueira, BRS Guatambu e BRS 277) x cinco densidades de semeadura $\left(75,150,225,300\right.$ e $375 \mathrm{~m}^{2}$ de sementes) x quatro operações de clipagem (zero, um, dois e três recortes), dispostos em três repetições. As medidas dos caracteres foram número de perfilhos férteis, rendimento de sementes, ângulo de folha de bandeira, teor de clorofila e floração. O genótipo BRS Tarumâ é superior em número de perfilhos férteis e índice de clorofila para todas as densidades de semeadura, assim como o florescimento é influenciado diretamente pelos manejos de corte. A densidade de semeadura de 75 sementes m-2 não é indicada para trigo de dupla finalidade independente do manejo de corte. $\mathrm{O}$ rendimento das sementes é amplificado pelo aumento da densidade de semeadura, entretanto, avançando nos níveis de recorte, há uma diminuição no rendimento de forragem.

PALAVRAS-CHAVE: Ajuste de copa das plantas. Competição intraespecífica. Plasticidade fenotípica. Triticum aestivum $\mathrm{L}$.

\section{REFERENCES}

CARVALHO, I. R.; NARDINO, M.; FOLLMANN, D. N.; DEMARI, G.H.; OLIVOTO, T.; PELEGRIN, A. J.; SZARESKI, V. J.; FERRARI, M.; ROSA, T. C.; KOCH, F.; AISENBERG, G. R.; PEDO, T.; AUMONDE, T. Z.; SOUZA, V. Q. Path analysis of grain yield associated characters in wheat (Triticum aestivum L.) Brasilians. Australian Journal of Crop Science, v. 11, n. 11, p. 1406, 2017.

CONAB, Companhia Nacional de Abastecimento. Safra 2017/18: Décimo segundo levantamento, setembro 2018. Brasília, DF, 2018. 155p.

FONTANELI, R. S.; AMBROSI, I.; SANTOS, H. P.; IGNACZAK, J. C.; ZOLDAN, S. M. Análise econômica de sistemas de produção de grãos com pastagens anuais de inverno, em sistema de plantio direto. Pesquisa agropecuária brasileira, Brasília, v.35, n.11, p.2129-2137, nov, 2000. https://doi.org/10.1590/S0100204X2000001100002

HASTENPFLUG, Marcel. Desempenho de cultivares de trigo duplo propósito sob doses de adubação nitrogenada e regimes de corte. 2009. 66f. Dissertação (Mestrado em Agronomia). Universidade Tecnológica Federal do Paraná. Pato Branco, 2009.

JESUS JÚNIOR, C.; SIDONIO, L.; MORAES, V. E. G.; Panorama das importações de trigo no Brasil. BNDES Setorial. Rio de Janeiro: Banco Nacional de Desenvolvimento Econômico e Social. n. 34, p. 389-420, 2011.

MARTIN, T. N.; SIMIONATTO, C. C.; BERTONCELli, P.; ORTIZ, S.; HASTENPFLUG, M.; ZIECH, M. F.; SOARES, A. B. Fitomorfologia e produção de cultivares de trigo duplo propósito em diferentes manejos de corte e densidades de semeadura, Ciência Rural, v. 40, n. 8, p. 1695-1701, 2010. https://doi.org/10.1590/S0103-84782010000800004

MARTIN, T. N.; STORK, L.; BENIN, G.; SIMIONATTO, C. C.; ORTIZ, S. Importância da relação entre caracteres em trigo duplo propósito no melhoramento da cultura. Bioscience Journal, Uberlândia, v. 29, n.6, p.1932-1940. 2013.

MEINERZ, G. R.; OLIVO, C. J.; FONTANELI, R. S.; AGNOLIN, C. A.; HORST, T.; BEM, C. M. Produtividade de cereais de inverno de duplo propósito na depressão central do Rio Grande do Sul. Revista Brasileira de Zootecnia, v.41, n.4, p.873-882, 2012. https://doi.org/10.1590/S1516-35982012000400007 
MORENO, J. A. Clima do Rio Grande do Sul, Porto Alegre, Secretaria de Agricultura, 1961, 42p.

SZARESKI, V. J.; CARVALHO, I. R.; KEHL, K.; LEVIEN, A. M.; ROSA, T. C.; BARBOSA, M. H.; DEMARI, G. H.; PIMENTEL, J. R.; TROYJACK, C.; MARTINAZZO, E. G.; SOUZA, V. Q.; VILLELA, F. A.; PEDO, T.; AUMONDE, T. Z. Research Article Phenotypic and predicted genetic approaches for genotype ranking of wheat seed yield in Brazil. Genetics and Molecular Research, v. 17, p. 1-13, 2018.

https://doi.org/10.4238/gmr18026

VON PINHO, R.G.; GROSS, M. R.; STEOLA, A. G.; MENDES, M. C. Adubação nitrogenada, densidade e espaçamento de híbridos de milho em sistema de plantio direto na região sudeste do Tocantins. Bragantia, v. 67, n. 3, p.733-739, 2008. https://doi.org/10.1590/S0006-87052008000300023

ZILIO, M.; PELOSO, J. A.; MANTOVANI, A. Produção de forragem e de grãos de trigo de duplo propósito submetido a diferentes densidades de semeadura, adubação nitrogenada e manejos de corte. Revista de Ciências Agroveterinárias, v.16, n.4, p.367-375, 2018. https://doi.org/10.5965/10.5965/223811711642017367 